\title{
РИМИНСКА НЕВЈЕСТА У ЕСЕЈИМА ФРАНЧЕСКА ДЕ САНКТИСА И МАРКА ЦАРА
}

\begin{abstract}
Судбина Франческе да Римини и њеног љубавника Паола из Дантеовог „Пакла” привукла је пажњу многих историчара књижевности, теоретичара књижевности и есејиста. Есеј о Франчески да Римини, између осталих, написали су Франческо де Санктис и Марко Цар. Рад ће показати по чему се разликују, а по чему су слична ова два есеја. Које ставове износи Де Санктис и како их објашњава, колико је у својим ставовима Марко Цар самосталан, а колико се пак ослања на италијанског историчара књижевности, познатог по томе што Франческу да Римини сматра првом женом модерног свијета.
\end{abstract}

Кључне ријечи: Франческо де Санктис, Марко Цар, Франческа да Римини, есеј.

Једна од најпознатијих епизода из Дантеовог „Пакла” јесте она о Франчески и Паолу, двоје љубавника, смјештених у други круг пакла. Франческо де Санктис дао је овој епизоди огромну важност, тврдећи да за многе Божанствена комедија представља само поменута два имена. Иронично је закључио да би се могла лијепа књига написати када би се сакупила сва „усмена и писмена мудровања" и лажни закључци о овим двијема личностима. Да би обесмислио сва та „усмена и писмена мудровања” и површне закључке, Де Санктис наводи нека од несувислих питања на која су поједини коментатори покушали да дају одговоре у вези са епизодом о Паолу и Франчески. ${ }^{1}$

\footnotetext{
*arezina.mirjana@gmail.com

${ }^{1}$ Тако Фосколо на прво питање - зашто је Данте испричао са толико симпатија ову епизоду, одговара да је фирентински пјесник становао у кући Гвида Полента, Франческиног оца, те да је можда видио њену собу, а можда је и чуо од породице за тај тужни случај. Друго питање тицало се проблема зашто је пјесник бацио у сјенку гријех, а истакнуо оно што је код грешнице племенито и њежно, а одговор је пронађен у објашњењу да је то због деликатности и због захвалности јер Данте као гост у кући Франческиног оца није хтио да срамоти његову ћерку. Сљедеће питање било је зашто није споменута значајна околност, било да је историја или предање, односно свирепа превара, с обзиром на то да је млада вјеровала да се удаје за Паола, а тек ујутру поред себе видјела његовог брата, хромог Ланћота. Фосколо одговара да је то због тога што се идеално приказивање није смјело оптеретити стварним догађајима јер би нарушили његову чистоту. На питање зашто је Данте спојио двоје заљубљених у паклу, Ђингвене одговара да за тако лак гријех нису у правом смислу ни осуђени, док Фосколо каже да је њихов гријех био
} 
Даље Де Санктис причу враћа у озбиљне оквире и савјетује нове генерације да оставе сличне преписке манастирким и кафанским доколичарима, а да се они навикавају да читају писце сами, без коментара, у директном контакту са писцима, закључујући да оно што се не разумије и не вриједи да буде схваћено, а лијепо је само оно што је јасно.

Управо, по Де Санктисовом мишљењу, једно од најљепших пјевања јесте и пјевање о Франчески баш зато што је најјасније, а његов кључан став тај је да „овој прворођеној Дантеовој ћерки” треба прићи са искључиво умјетничким осјећањем и са једином намјером да посматрамо и уживамо. Истиче да није важно како је Данте дошао до замисли о Франчески, а још мање је важно шта је пјесник мијењао или искривио у историјској традицији јер је Франческа, онаква какву ју је Данте замислио, много живља и истинитија него што би могла бити да нам је да историја. Таква Франческа је, тврди, прворођена, прва жива и права жена која се појавила на поетском хоризонту модерног доба. Да би објаснио животност Франческе, Де Санктис прави разлику између Беатриче и Франческе. Тако је Беатриче љепота, врлина, мудрост, бестјелесна и истанчана индивидуа која и не представља више индивидуу, већ тип и род, она није жена, већ женски род, Гетеово вјечито женско. Франческа је индивидуа, ослобођена сваког хетерогеног елемента, која није више појам, или тип, или персонификација, већ права и стварна личност у свој својој слободи. Ту се крије, по Де Санктисовом мишљењу, и разлог мање популарности Дантеове велике љубави у односу на Франческу јер је Беатриче род или тип, а не индивидуа, можемо да јој се дивимо, да је обожавамо, да је схватимо, да је објаснимо, али не да је волимо, она не може да буде наша преко чисто естетског уживања јер смо на одстојању од ње. За разлику од ње, Франческа је стекла огромну популарност и код многих она је једина фигура која је надживјела Божанствену комедију.

Де Санктис детаљно анализира Франческине особине. Она је жена, ништа друго до жена, она је идеална, али није идеал нечег другог, већ идеал саме себе, и то сасвим остварени идеал. Можда и најоригиналније изнесен став у овом есеју јесте тај када Де Санктис тврди да је Данте несвјесни Едип, који је овдје убио сфингу и потпуно освојио жену, а жену коју је тражио у рају, нашао је у паклу. „Франческа није божанско, већ људско, земаљско,

веома тежак, а самилост Бога била је већа, па је он хтио да има обзира према толикој љубави и да умањи казну допуштајући им да се воле и у паклу. Један коментатор поређење са голубовима протумачио је аргументом да су голубови необично сладострасне животиње, док је Магалоти објаснио да је разлог што је пјесник пустио Франческу да говори тај јер су жене по природи брбљивије, а Фосколо тврди да жене када су обухваћене страшћу осјећају потребу да говоре и да дају себи одушка. Де Санктиса је, очито, највише наљутило објашњење једног фратра да Данте осјећа толику бол да му се ум губи „од сажаљења према овим рођацима” зато јер се свако сјетио да је починио сличан гријех. Сувишност бесмислених питања поткрепљује још једним примјером, који се тиче Петрарке. Наиме, наводи да је добио писмо од три ученика лицеја из Барија, а они су га питали зашто је Петрарка писао Канционијер на италијанском, а не на латинксом. Де Санктис се иронично поиграва са питањем, па каже да је пао у ружно искушење, те да је хтио младићима одговорити да је разлог писања на италијанском то што Лаура није знала латински. Међутим, како наводи, учинило му се свирепим да одговори шалом младићима који су тако озбиљно расправљали. 
ломно и нежно биће, страсно, способно да греши и грешно и због тога у таквој ситуацији да су све њене моћи стављене у покрет са дубоким контрастима који рађају неодољиве емоције” (Де Санктис 1960: 62). С обзиром на то да у Франческину душу не може да уђе ниједно друго осјећање осим љубави, а та љубав приказана је као несавладива сила, италијански есејиста сматра да у овом случају имамо слабост, а не поквареност, па је, по његовим ријечима, Франческа остала тип из кога су произашла најдража створења модерне маште: ломна бића, код којих се ништа не опире и не реагује, крхки цвјетови за које је сваки дашак смртан, бића која личе сва једно на друго због заједничке природе (Исто: 62).

Епизода о Франчески, али и Де Санктисов есеј, инспирисали су српског есејисту Марка Цара да напише есеј о риминској невјести. Написао га је поводом шесте стогодишњице Дантеове смрти, а као увод за овај есеј послужила му је дубровачка књижевност. Цар почиње свој есеј износећи став да је ова књижевност највећи и најљепши украс старог Дубровника, те да је она „безмало кроз три века представљала готово целу књижевну делатност нашег народа" (Цар 1936: 119 ). Истиче да се под утицајем италијанске ренесансне књижевности и културе Дубрвник претворио у „средиште префињене уљудности и културе”, те да су се у њему његовале наука и култура, међутим, погрешно закључује да се у старом Дубровнику књижевношћу бавила само властела. Разлог помињања дубровачке књижевности и још неких карактеристика старог Дубровника (обраћали су главну пажњу на управу и трговину, а књижевношћу су се више бавили као дилетанти, књижевност су сматрали као пријатну разоноду, стварали су углавном по љетњиковцима у близини града) Цар проналази у подразумијеваности да се Данте не може одвојити од значајног културног покрета који је створио дубровачку књижевност. И након успостављања ове везе, Цар и даље пише о ситуацији у старом Дубровнику, а не о Дантеу и о епизоди о Франчески и Паолу. Закључује да се ренесанса у Дубровнику није развијала само путем књиге и науке већ и захваљујући сталним и живим везама образованих људи са прекоморским свијетом. Тако су, сматра Цар, дубровачки госпари читали Дантеову Божанствену комедију са истим уживањем као они у Фиренци, њу је читала и Цвијета Зузорић, а затим износи неке податке у вези са овом чувеном дубровачком љепотицом. Мора се признати да то што је она са својим мужем „у браку провела пуних шеснаест година и ког јој смрт отрже из наручја кад је млада и лепа жена била тек прешла своју тридесет и шесту годину живота" (Цар 1936: 121) нема баш много везе са Дантеом. И остали подаци које Цар износи о Цвијети Зузорић немају везу са Дантеом и чувеном епизодом из „Пакла”, а Цар везу успоставља тако што каже да ми волимо да Зузорићеву у својим мислима гледамо како као удовица, сјећајући се своје изгубљене среће, сјетно понавља Дантеову терцину:

Nessun maggior dolore

Che ricordarsi del tempo felice

Nella miseria 
али да волимо и да је видимо како „устрепталом душом прати загрљене сенке Паола и Франческе".

Тек након овог преопширног увода Цар прелази на саму тему и пише о познатој епизоди из Дантеовог „Пакла”, истичући да љубавна историја што се везује за ова два бесмртна лица иде у пјесничке творевине које имају то „ретко преимућство да се допадају и простим и сложеним духовима”, чак имају ту чудесну моћ да му се диве најразличитији погледи, те да човјек ту више „не разлаже: он просто саосећа и ћути”. Помиње причу која се везује за Франческу и њену удају на превару, а мотив вјенчања на превару проналази и у нашој народној пјесми „Женидба Максима Црнојевића”. Препознавање овог мотива у епској поезији и његово повезивање са позадином приче о Паолу и Франчески најзначајнији је и најоригиналнији дио Царевог есеја. Након овог препознавања препричава пето пјевање, а препричавање поткрепљује стиховима из Пакла које наводи и у оригиналу и у преводу. Оградио се од превода, за који каже да је безбојан, готово импровизован, али значајно је то што износи став о превођењу Божанствене комедије у стиху, па тврди да о добром стиховном преводу не може бити ни говора. Франческину исповијест Цар је оцијенио као пуну ријечи у којима је „толико сетне милоште и којима као да Франческа прашта своме драгану што се због њега упропастила, те дивном женском нежношћу признаје да га још једнако воли" (Цар 1936: 125). Сматра да је Данте заобишао кривицу двоје љубавника из њиховог земног живота, а својом умјетношћу успио да нам представи као један диван примјер љубави и у животу и у смрти оно што људски закони осуђују.

Саму Франческу Марко Цар описује искључиво на основу Де Санктисових ријечи, односно оног познатог Де Санктисовог начина да Франческу опише правећи разлику у односу на Беатриче. Интересантно је да Цар онај Гетеов став „вјечито женско” наводи на њемачком језику Das ewig Weibliche, док Де Санктис у издању које цитира Цар² користи италијански термин l'eterno femminile di Goethe. Износи још један Де Санктисов став о земаљској природи Франческе, а затим га цитира. Царев превод дијелова Де Санктисовог есеја остављамо за стручне преводиоце, међутим, оно што се мора нагласити јесте чињеница да у току тог цитирања он није прецизан, преузима Де Санктисове ријечи са шесте, седме и осме стране поменутог есеја, али том приликом прескаче реченице, не наводећи то. Цитира и Де Санктисову реченицу у којој говори о трагедији жене, измијењеној хиљадама различитих случајева, али са истом основом. Као примјер наведени су књижевни ликови: Офелија, Јулија, Клара, Текла, Маргарета и Франческа (у његовом преводу Маргарета је Гретхен). Цар завршава свој есеј ставом да се ми Дантеовој Франчески не само дивимо него је и разумијемо и волимо.

Она је дивно оличење неодољиве, суверене љубавне страсти, она је као песничка креација напросто јединствена. Слушајући њено умиљато и, у својој искрености, безазлено гукање, ми се налазимо као у некој двоумици, те сами себе питамо кога имамо испред себе: да ли грешну Риминску невесту, или невину Шекспирову Јулију? (Цар 1936: 129)

${ }^{2}$ Francesco De Sanctis, Nuovi Saggi Critici, Napoli, 1879, стр. 5. 
Ово запажање није оригинално Царево, то је упрошћен, иначе одлично објашњен Де Санктисов став о малој граници између чедности и страсти код Франческе:

Франческа ништа не крије, ништа не прикрива. Признаје са савршеном чедношћу своју љубав; нити се жали, нити се каје, нити тражи олакшавајуће околности, и не почиње да расправља против бога. - Паоло ме је заволео јер сам била лепа, и ја сам га заволела јер ми је било мило да будем вољена, и уживала сам у његовом уживању. - Такве ствари просте жене немају обичај да признају ни на ухо. Назива лепим телом оно у које се Паоло заљубио, назива уживањем осећање које је још не напушта; и када јој је Паоло сав уздрхтао пољубио уста, свакако да његово тело није дрхтало од страха. Овде имамо праву и чисту страст, интензивну жељу пуну сладострашћа. Али уз то налазимо осећање које пречишћава и чедност што враћа девичанство; тако се у том љупком говору тешко разазнаје да ли је пред нама грешна Франческа или невина Ђулијета (Де Санктис 1960: 64).

И већ поменут Царев став да љубавна историја што се везује за ова два бесмртна лица иде у пјесничке творевине које имају то ,ретко преимућство да се допадају и простим и сложеним духовима” (Цар 1936: 122) није оригиналан. Преузет је од Де Санктиса, који је написао да је Франческа стекла огромну популарност и код мање културних народа, те да је код многих једина фигура која је надживјела Божанствену комедију.

Есеј Марка Цара разликује се од Де Санктисовог по једној битној особини. Де Санктис пише о Паолу, док га Цар не спомиње. Паоло, по Де Санктисовом мишљењу, није човјек:

[...] мушкарац који би требало да буде антитеза и да успостави неки дуализам. Франческа испуњава собом целу сцену. Паоло је неми израз Франческин; он је струна која треперењем изражава оно што реч казује; покрет који прати глас; једно говори, друго плаче; плач једнога је реч другога; то су два голуба које носи иста жеља, тако да када их испрва чујемо, не знамо који од њих говори а који ћути, и у толикој сличности готово нам се чини да из обоје излази исти глас (Де Санктис 1960: 68).

Такође, за разлику од Цара, Де Санктис даје одговор и на питање зашто је пјесник учинио нераздвојним ова два срца, зашто је од два начинио једно, те зашто љубав живи када је умрла нада. По његовом мишљењу њих двоје се вјечно воле управо зато што су осуђени; ,,јер док је у рају земаљско уздигнуто до божанског, у паклу земаљско остаје вечито и непромењиво; јер у Дантеовом паклу грешници задржавају исте страсти, и због тога су огрезли у греху и осуђени" (Де Санктис 1960: 68).

Ова два есеја разликују се у још једној битној особини: тумачењу гријеха. Де Санктис тврди да у епизоди о Франчески и Паолу нема ниједне и најмање појединости на којој није написано гријех, а да је између тренутка када се Франческа заљубила и њене смрти протекла цијела једна историја, историја љубави и гријеха. Сматра да је гријех највиши патос трагедије, јер ова противрјечност љубави није убачена споља, она је у самој души заљубљених. Даје одлично објашњење да је љубав без противрјечности аркадска проза, Дафне и Клое. Јер када противрјечност произилази из акциденталних препрека (породични разлози, политичка мржња), заљубљени су свјесни да је право на њиховој страни и боре се против препрека постављених ван њихове свијести. Међутим, с обзиром на то да је гријех бескрајан као и љубав, ово 
тумачење завршава кључном реченицом да ако се уништи свијест о гријеху, уништиће се Франческа да Римини, коју је Ауербах, између осталих, сврстао у „племените проклетнике” (1968: 201). Банализујући цијели еп, Цар се везује за кажњавање гријеха и закључује да је ,тиме што је своја песничка чеда стрпао у пакао" пјесник учинио знатан уступак моралу свог времена и наређењима своје цркве. Али, по Царевом мишљењу, Данте је у души осјетио како онај ко је много волио има право да му се много и опрости, те је на пакао осуђене грешнике спојио у вјечности. У пакленим мукама могу се тјешити тиме што су заувијек здружени.

На почетку есеја Де Санктис је дао важност цијелој епизоди о Паолу и Франчески, док је на крају она усмјерена на Франческу, па је истакнуто да италијанска поезија није имала много среће у приказивању жене, те да је Франческа једина, усамљена јер из толико лирских пјесама није произашла ни једна једина жива жена.

Де Санктисов есеј много је свеобухватнији, детаљнији и исцрпнији. Есеј Марка Цара више је општи, без детаљне анализе Франческиног лика, а анализа се свела на цитирање Де Санктиса. Ипак, похвално је да је шестогогодишњица смрти великог италијанског пјесника Дантеа и на овај начин обиљежена у српској књжевности, а Марко Цар је најзахвалнији што је писано тим поводом.

\section{ЛИТЕРАТУРА}

Ауербах 1968: Е. Ауербах, Мимезис - Приказивање стварности у западној кюижевности, Београд: Нолит.

Де Санктис 1879: F. De Sanctis, Nuovi Saggi Critici, Napoli.

Де Санктис 1960: F. De Sanktis, Kritički eseji, Beograd: Kultura.

Цар 1936: М. Цар, Есеји, Београд: Српска књижевна задруга.

Mirjana D. Arežina

FRANCESKA DA RIMINI IN ESSAYS OF FRANCESCO DE SANCTIS AND

MARKO CAR

(Summary)

The fate of Francesca da Rimini and her lover Paolo from Dante's Divine Comedy has drawn attention of many historians of literature, theoreticians of literature and essayists. Among others, Francesco de Sanctis and Marko Car have written essays on Francesca da Rimini. This paper will show similarities and differences between the two essays and try to answer these questions: which views does de Sanctis express and explain, to what extent is Marko Car independent and how much does he rely on Italian historian of literature, known by his notion that Francesca da Rimini is the first woman of the modern world. 